\title{
MAHGOUB TRANSFORM AND HYERS-ULAM STABILITY OF FIRST-ORDER LINEAR DIFFERENTIAL EQUATIONS
}

\section{Soon-Mo Jung*, Ponmana Selvan Arumugam and Murali Ramdoss}

Abstract. The main aim of this paper is to investigate various types of Hyers-Ulam stability of linear differential equations of first order with constant coefficients using the Mahgoub transform method. We also show the Hyers-Ulam constants of these differential equations and give some examples to better illustrate the main results.

Mathematics subject classification (2020): 34A40, 39B82, 26D10, 44A15.

Keywords and phrases: Mahgoub transform, Mahgoub transform method, Hyers-Ulam stability, HyersUlam $\phi$-stability, differential equation.

\section{REFERENCES}

[1] S. Aggarwal, N. Sharma And R. Chauhan, Solution oflinear Volterra integro-differential equations of second kind using Mahgoub transform, International Journal of Latest Technology in Engineering, Management and Applied Science 7 (2018), no. 5, 173-176.

[2] Q. H. ALQIFIARY AND S.-M. JUNG, Laplace transform and generalized Hyers-Ulam stability of differential equations, Electron. J. Differential Equations 2014 (2014), no. 80, 1-11.

[3] C. Alsina AND R. GER, On some inequalities and stability results related to the exponential function. J. Inequal. Appl. 2 (1998), 373-380.

[4] T. AOKI, On the stability of the linear transformation in Banach spaces, J. Math. Soc. Japan 2 (1950), 64-66.

[5] D. G. Bourgin, Classes of transformations and bordering transformations, Bull. Amer. Math. Soc. 57 (1951), 223-237.

[6] A. BUAKIRD AND S. SAEJUNG, Ulam stability with respect to a directed graph for some fixed point equations, Carpathian J. Math. 35 (2019), no. 1, 23-30.

[7] R. FUKUTAKA AND M. ONITSUKA, Best constant in Hyers-Ulam stability of first-order homogeneous linear differential equations with a periodic coefficient, J. Math. Anal. Appl. 473 (2019), 1432-1446.

[8] J. HuAnG, S.-M. Jung AND Y. Li, On Hyers-Ulam stability of nonlinear differential equations, Bull. Korean Math. Soc. 52 (2015), 685-697.

[9] D. H. HYERS, On the stability of a linear functional equation, Proc. Natl. Acad. Sci. USA 27 (1941), 222-224.

[10] S.-M. Jung, Hyers-Ulam stability of linear differential equation of first order, Appl. Math. Lett. 17 (2004), 1135-1140.

[11] S.-M. Jung, Hyers-Ulam stability of linear differential equations of first order (III), J. Math. Anal. Appl. 311 (2005), 139-146.

[12] S.-M. JUnG, Hyers-Ulam stability of linear differential equations of first order (II), Appl. Math. Lett. 19 (2006), 854-858.

[13] S.-M. JUNG, Hyers-Ulam stability of a system of first order linear differential equations with constant coefficients, J. Math. Anal. Appl. 320 (2006), no. 2, 549-561.

[14] V. Kalvandi, N. Eghbali and J. M. Rassias, Mittag-Leffler-Hyers-Ulam stability of fractional differential equations of second order, J. Math. Extension 13 (2019), no. 1, 29-43.

[15] Y. Li AND Y. SHEN, Hyers-Ulam stability of linear differential equations of second order, Appl. Math. Lett. 23 (2010), 306-309. 
[16] T. Li, A. ZADA AND S. FAISAL, Hyers-Ulam stability of $n$th order linear differential equations, J. Nonlinear Sci. Appl. 9 (2016), 2070-2075.

[17] T. Miura, On the Hyers-Ulam stability of a differentiable map, Sci. Math. Jpn. 55 (2002), 17-24.

[18] R. Murali, A. Bodaghi And A. P. Selvan, Stability for the third order linear ordinary differential equation, Int. J. Math. Comput. 30 (2019), no. 1, 87-92.

[19] R. Murali And A. P. Selvan, On the generalized Hyers-Ulam stability of linear ordinary differential equations of higher order, Int. J. Pure. Appl. Math. 117 (2017), no. 12, 317-326.

[20] R. Murali And A. P. Selvan, Hyers-Ulam-Rassias stability for the linear ordinary differential equation of third order, Kragujevac J. Math. 42 (2018), no. 4, 579-590.

[21] R. Murali And A. P. Selvan, Ulam stability of third order linear differential equations, Int. J. Pure. Appl. Math. 120 (2018), no. 9, 217-225.

[22] R. Murali And A. P. Selvan, Hyers-Ulam stability of $n$th order linear differential equation, Proyecciones: Journal of Mathematics (Revista de Matematica) (Antofagasta online), 38 (2019), no. 3, 553-566.

[23] R. Murali And A. P. Selvan, Fourier transforms and Ulam stabilities of linear differential equations, Frontiers in Functional Equations and Analytic Inequalities 2019 (2019), 195-217.

[24] R. Murali And A. P. SElvan, Hyers-Ulam stability of a free and forced vibrations, Kragujevac J. Math. 44 (2020), no. 2, 299-312.

[25] R. Murali, A. P. Selvan and C. Park, Ulam stability of linear differential equations using Fourier transform, AIMS Mathematics 5 (2019), no. 2, 766-780.

[26] M. OBŁOZA, Hyers stability of the linear differential equation, Rocznik Nauk.-Dydakt. Prace Mat. 13 (1993), 259-270.

[27] M. OвŁozA, Connections between Hyers and Lyapunov stability of the ordinary differential equations, Rocznik Nauk.-Dydakt. Prace Mat. 14 (1997), 141-146.

[28] M. ONITSUKA, Hyers-Ulam stability of first order linear differential equations of Caratheodory type and its application, Appl. Math. Lett. 90 (2019), 61-68.

[29] M. ONITSUKA AND T. Shoji, Hyers-Ulam stability of first order homogeneous linear differential equations with a real valued coefficients, Appl. Math. Lett. 63 (2017), 102-108.

[30] J. M. RASSIAS, On approximately of approximately linear mappings by linear mappings, J. Funct. Anal. 46 (1982), 126-130.

[31] J. M. Rassias, R. Murali And A. P. Selvan, Mittag-Leffler-Hyers-Ulam stability of linear differential equations using Fourier transforms, J. Comput. Anal. Appl. 29 (2021), no. 1, 68-85.

[32] TH. M. Rassias, On the stability of the linear mappings in Banach Spaces, Proc. Amer. Math. Soc. 72 (1978), 297-300.

[33] H. Rezaei, S.-M. Jung And Th. M. Rassias, Laplace transform and Hyers-Ulam stability of linear differential equations, J. Math. Anal. Appl. 403 (2013), no. 1, 244-251.

[34] I. A. RUS, Ulam Stabilities of ordinary differential equations in a Banach space, Carpathian J. Math. 26 (2010), no. 1, 103-107.

[35] S. E. Takahasi, T. Miura And S. Miyajima, On the Hyers-Ulam stability of the Banach spacevalued differential equation $y^{\prime}=\alpha y$, Bull. Korean Math. Soc. 39 (2002), 309-315.

[36] S. M. Ulam, Problem in Modern Mathematics, Chapter IV, Science Editors, Willey, New York, 1960.

[37] H. VAEZI, Hyers-Ulam stability of weighted composition operators on disc algebra, Int. J. Math. Comput. 10 (2011), 150-154.

[38] G. WANG, M. ZHOU AND L. Sun, Hyers-Ulam stability of linear differential equations of first order, Appl. Math. Lett. 21 (2008), no. 10, 1024-1028. 